\title{
AN ARCHITECTURAL PATTERN IN LATE FOURTH-MILLENNIUM BC WESTERN IRAN: A NEW LINK BETWEEN SUSA, TAL-I MALYAN, AND GODIN TEPE
}

\author{
By F. Desset \\ University of Tehran/UMR 7041 (ArScAn)
}

\begin{abstract}
This paper presents a recurrent architectural pattern - unnoticed up to now-observed in late fourth-millennium BC strata at the Iranian sites of Susa, Tal-i Malyan, and Godin Tepe. On the basis of this evidence, the article proposes some considerations for understanding aspects of the period characterised by the so-called "Proto-Elamite phenomenon".
\end{abstract}

Keywords

Architecture; Uruk phenomenon; Proto-Elamite phenomenon; Iran; Godin Tepe; Tal-i Malyan; Susa

\section{INTRODUCTION}

The fourth millennium BC is an important moment in world history, fascinating because, from many points of view, it presages the origins of our current way of life. In these centuries, cities such as Uruk/Warka, Tell Brak, and Hamoukar appeared in Mesopotamia (Uruk/ Warka reaching 250 ha at the end of the Uruk period). Writing systems were invented in southern Mesopotamia and on the Iranian plateau ${ }^{1}$ and what might be called a material proto-globalisation-the "Uruk expansion"-was attested from Syria and Turkey to eastern Iran (Fig. 1).

Since Algaze presented his concept of an Uruk expansion, ${ }^{2}$ the responses of the archaeological commu-

1 The main current hypothesis considers the Iranian ProtoElamite writing (PE writing) as a "daughter" of the southern Mesopotamian proto-cuneiform one. From radiocarbon datings and logical arguments, I recently proposed to view these writings as "contemporaneous sisters" (Desset 2012: 63-81; see also Petrie, forthcoming, a and b, who is close to this statement: "It appears increasingly likely that we have evidence for a partially overlapping development of the Mesopotamian and Iranian proto-literate scripts"/“Questions are now also being posed about the precise chronological relationship between the Uruk and Proto-Elamite phenomena, and the possibility that there was some degree of contemporaneous development for the two traditions during the late fourth millennium BC") [Desset's emphases].

$2 \quad$ Algaze 1989.

Iran LII 2014, 1-18 $\quad$ C 2014 The British Institute of Persian Studies nity can be reduced to two different orders of hypothesis: ${ }^{3}$ a minimalist one, for which the similarities in material culture assemblages are simply due to general cultural influence from Mesopotamia, or the more specific viewpoint, advocated by Algaze and others, proposing that the Uruk-related material was transported from Mesopotamia northwards and eastwards by shifting human groups through a variety of processes.

At one level this archaeological phenomenon is mainly described in terms of influence from southern Mesopotamia over its northern and eastern neighbours, achieved through the foundations of various colonies and outposts with the aim of controlling access to and acquiring raw materials. ${ }^{4}$ More recent trends in archaeological research, however, emphasise the complexity of the relationships between the proposed southern Mesopotamian core and its peripheries, and place emphasis on local developments rather than external influences. ${ }^{5}$ For example, the Oval enclosure of Godin Tepe (phase VI.1) was initially perceived as an enclave of "Susian traders", 6 a place "occupied by people from lowland Mesopotamia" or a "small diaspora community of Uruk origin" existing "in larger

\footnotetext{
See Petrie 2013a for a clear updated summary on the state of play.

4 See inter alia, Algaze 2005.

5 Helwing 2005: 52.

6 Weiss and Young 1975: 13-16.

7 Young 1986: 218.
} 


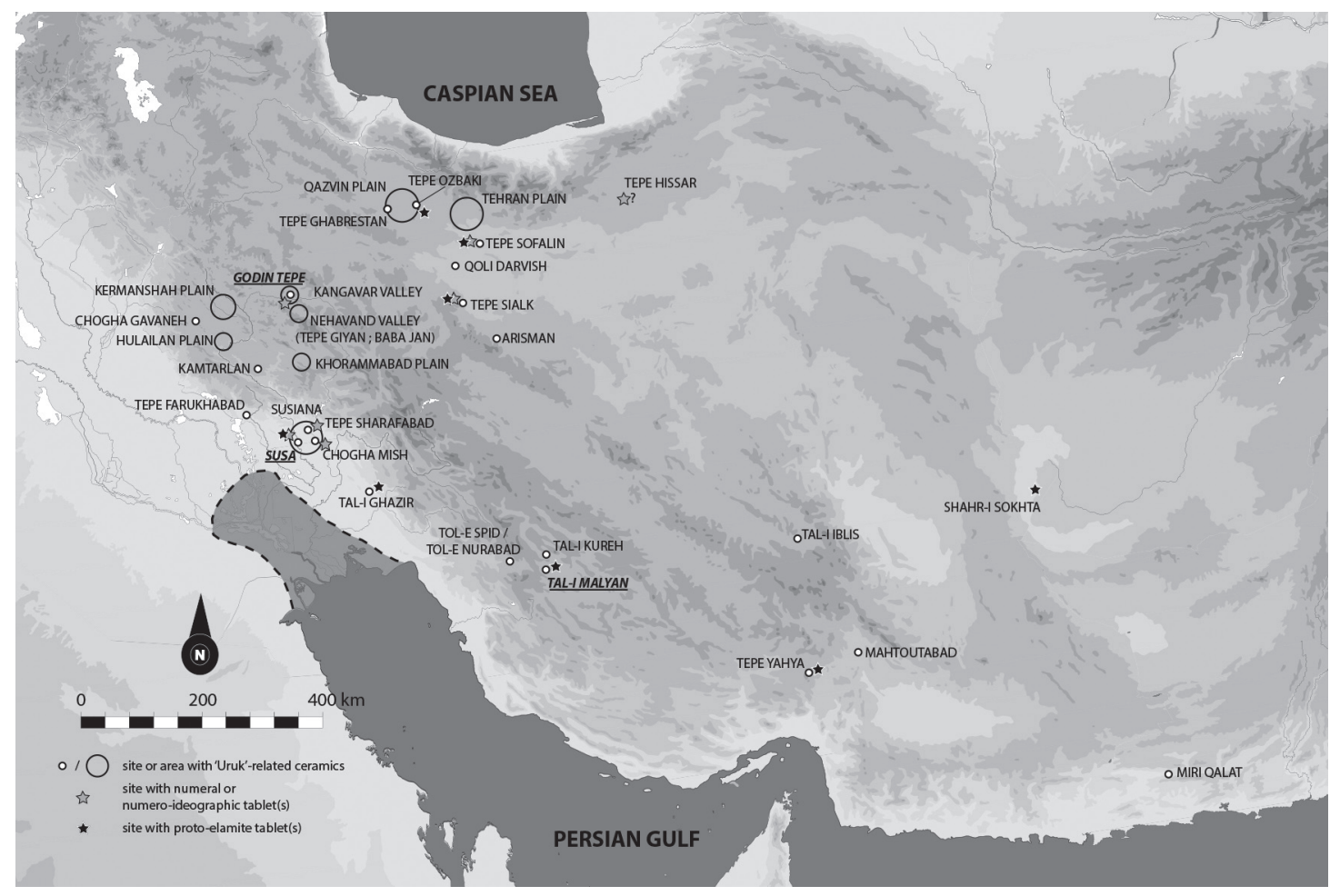

Fig. 1. An archaeological map of late fourth-millennium BC Iran.

preexisting centers with the consent of local populations". ${ }^{8}$ More recently, however, it has been described as an example of an "independent center with Uruk contact", inhabited by "local leaders" influenced by lowland Mesopotamia. ${ }^{9}$

While such general interpretations help us to conceive this history, this paper is primarily intended to point out a material fact that, since the 1970 s, seems to have escaped attention: ${ }^{10}$ an architectural pattern common to Godin Tepe VI.1 (the Oval enclosure), Susa Acr. I.16, and Tal-i Malyan ABC IV, ABC III, and TUV II. This link attests that material remains left by human societies, such as ceramics, glyptic, writing,

8 Amiet 1986: 71-73; Algaze 2005: 132; Matthews (2013: 347) argues that the use of writing technology in the Oval enclosure of Godin Tepe shows "the presence of at least a small group of Uruk origin people".

9 Rothman and Badler 2011: 113, 119; Rothman 2013: 80, 84, 88-90; Petrie 2013b: 397.

10 The plans of the buildings dealt with here were first published in 1971 for Susa (Le Brun 1971), in 1975 for Godin Tepe (Weiss and Young 1975), in 1976 for Tal-i Malyan ABC IV and III (Sumner 1976), and in 1980 and 1990 for Tal-I Malyan TUV II (Nicholas 1980, 1990). or architecture, may be independent issues, thus calling into question the archaeological notion of a single coherent and recurrent (Urukean/Proto-Elamite) material assemblage.

\section{THE ARCHITECTURAL EVIDENCE}

\section{II.1 Godin Tepe}

In the western Zagros site of Godin Tepe a famous architectural compound, the Oval enclosure (Fig. 2) ${ }_{11}^{11}$ was excavated in 1973. Built in the last occupation phase of period VI (phase VI.1), ${ }^{12}$ several radiocarbon dates

11 Weiss and Young 1975; Young 1986; Amiet 1986: 71; Badler 2002: 82-83; Rothman and Badler 2011: 92-99; Rothman 2013: 81-84; Matthews 2013.

12 The Oval enclosure was initially attributed to period V ("Uruk"-related type material period), supposedly later than period VI, before excavators realised that the local Godin VI ceramics and the Mesopotamian linked ones (Godin V) were contemporaneous (Young 1986: 212). A new archaeological sequence was then proposed (Young 2004: 648; Rothman 2005: 59; Rothman and Badler 2011: 82): 


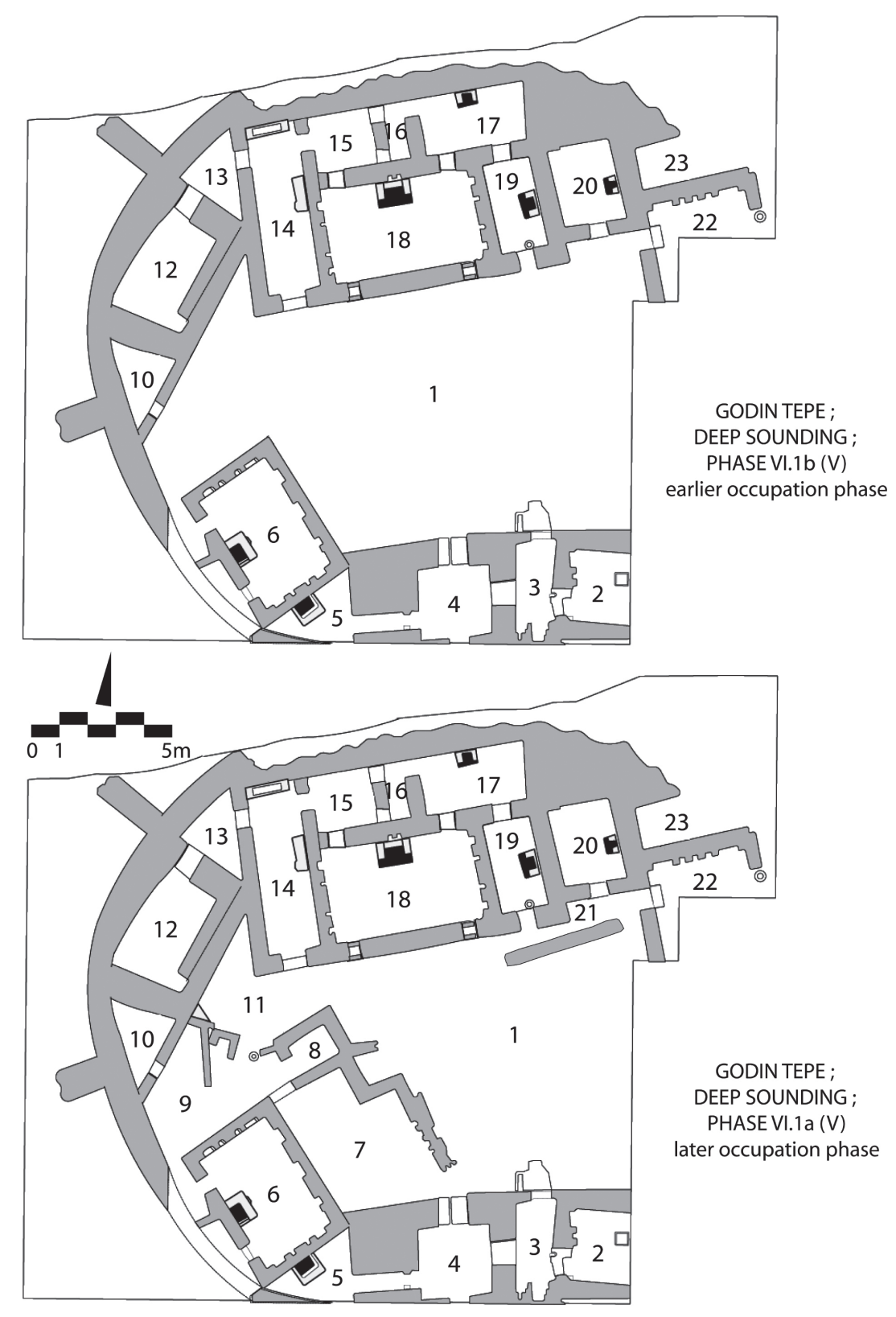

Fig. 2. Godin Tepe, the Oval enclosure compound, phase VI.1 (previously period V), second halflend of the fourth millennium BC (from Badler 2002: fig. 5; Rothman and Badler 2011: figs. 4.18 and 4.19).

— VI.3: phase with local material assemblage, prolonging period VII (was it necessary to make a distinction between period VII and phase VI.3 since they are theoretically characterised by a similar assemblage?);

—VI.2: "Uruk"-related artefacts appeared, while local material was still in use, before the Oval enclosure was built (phase identified by Badler 2002 in Op. B in the Brick Kiln Cut); — VI.1: the Oval enclosure was built while "Uruk"-related and local assemblages were still being used. situate its main occupation to between 3500/3350 and $3100 \mathrm{BC}^{13}$ while, according to Badler, the last occupation floors of the complex are to be dated c. $3000 \mathrm{BC} .{ }^{14}$

13 Voigt and Dyson 1992: 2: 134-35; Young 1997; Wright and Rupley 2001: 94-96; Rothman and Badler 2011: table 4.2; Desset 2012: 70: Dahl et al. 2013: fig. 18.9; Petrie, forthcoming, $b$.

14 Badler 2002: 89, n. 13. 
Partially excavated in an exposure of $550 \mathrm{~m}^{2}$, the Oval enclosure appears to have had only one entrance, from room 4 (perhaps with a tower above), giving access to an inner courtyard (1) inside which were three very similar main rooms: 6,18 , and $22 .{ }^{15}$ Rooms 6 and 18 possessed a rectangular hearth built in the middle of a long wall with two doors equidistant on either side of the central hearth (there are also similar hearths in rooms 5, 17, 19, and 20). ${ }^{16}$ These main rooms were decorated with several vertical niches ${ }^{17}$ while two windows opening on courtyard 1 were set in the southern wall of room 18. Charred beams discovered in room 22 indicate that the rooms of the Godin Oval were generally covered by flat roofs built of wooden beams, branches, and pisé. Several walls in the Oval enclosure are so large (nearby rooms 4, 17, 19, 20, 23) that they were perhaps used to support upper floors or a terrace.

Several construction sub-phases have been distinguished in the Oval enclosure (sub-phases VI.1b, then VI.1a). The wall separating rooms 12 and 13 or the walls defining areas 7, 8, 9, and 11 were built in a second stage. It was also probably the case for room 14, whose construction might be linked to the addition of the partition wall between rooms 15 and 16 (originally, only two rooms with similar sizes gave access to room 18: rooms 17 and 15/16). Finally, the doors between rooms 4 and 3, 3 and 2, 10 and 9, and 12 and 13 were all blocked, sealing off rooms 3, 2, 12, and 10 .

Inside the complex, an "Uruk"-related material assemblage was found, consisting of ceramic vessels, numeral tablets (one also displayed a logogram), and seals/sealings related to Susa Acr. I.17, according to Pittman. ${ }^{18}$ Although the Oval enclosure monopolised most of the "Uruk"-related artefacts dug out in Godin Tepe (bevel-rim bowls [BRBs] and low-sided trays were also found outside this building), it also contained many local ceramics and a huge quantity of clay balls (notably 1758 balls in room 18).

This architectural complex was previously mainly compared with Mesopotamian examples, such as

15 The dimensions of rooms 6 and 18 , as well as of rooms 17 and $15 / 16$, were all characterised by a ratio of length to width of $1.6 / 1$.

16 Two flues were also constructed behind the hearth in room 18.

17 Said to be "probably used as storage shelves" from ethnographic parallels (Rothman and Badler 2011: 94; Rothman 2013: 82).

18 In Rothman and Badler 2011: 114.
Amiet, ${ }^{19}$ who compared it with Tepe Gawra XIII, Forest, who saw the influence of a Urukean pattern in the architecture excavated in Arlsan Tepe, Susa (Acr. I.17B), and Godin Tepe (the Oval enclosure ${ }^{20}$ or Matthews. ${ }^{21}$ Several authors nevertheless noticed that the Oval enclosure did not completely match these western comparisons. ${ }^{22}$

\section{2 Susa}

In the excavations at Susa between 1968 and 1978 under the supervision of J. Perrot, A. Le Brun was in charge of the trench Acropolis I. His excavations established an archaeological sequence including twenty-seven layers spanning the most ancient times of Susa, between the end of the fifth and the beginning of the third millennium BC (layers 27-14/13), and illustrating the invention of writing from bullae and tokens to Proto-Elamite (PE) tablets. Unfortunately, this very precise and meticulously recorded excavation was not documented by any radiocarbon dates, leaving only ceramic comparisons to link these layers to the Middle Eastern absolute chronology.

In Acropolis I, layers 16 to 14 (Susa III) are characterised by the presence of PE tablets while the ceramic assemblage is partly modified after the stratigraphic hiatus with layer 17 . The main ceramic types are still "Uruk"-related ones ${ }^{23}$ such as BRBs, "flower pots", low-sided trays, or jars with conical spouts, but a new

19 1986: 72.

20 According to Forest (1999: 172-75), the main building of the Godin Tepe Oval enclosure was an adaptation of the bipartite reception rooms discovered in Djebel Aruda and Habuba Kabira.

21 Matthews 2013: 349: "Uruk-inspired architects coerced local builders into constructing Lower-Mesopotamian style buildings within the Oval enclosure".

22 Forest 2000: 146: “Godin Tépé, par exemple, n'est pas une enclave urukéenne, mais le fait de proto-élamites acculturés, comme le montre à l'évidence le caractère très particulier de l'architecture dégagée". [Desset's emphasis?]

Badler 2002: 84: "The rectangular hearths built against the long wall of the buildings of the Godin Tepe oval complex are also quite different from the typical Uruk free standing 'frying pan' hearths located in the center of the room". [Desset's emphasis?]

Algaze 2005: 53: "The fort itself was built in a nonUruk style that conformed to local highland canons [but what are these canons ?]". [Desset's emphases?]

23 Le Brun 1971: 192-93, 199-201; 203-5; 1978: 183, 190; Dittman 1986: 171. 


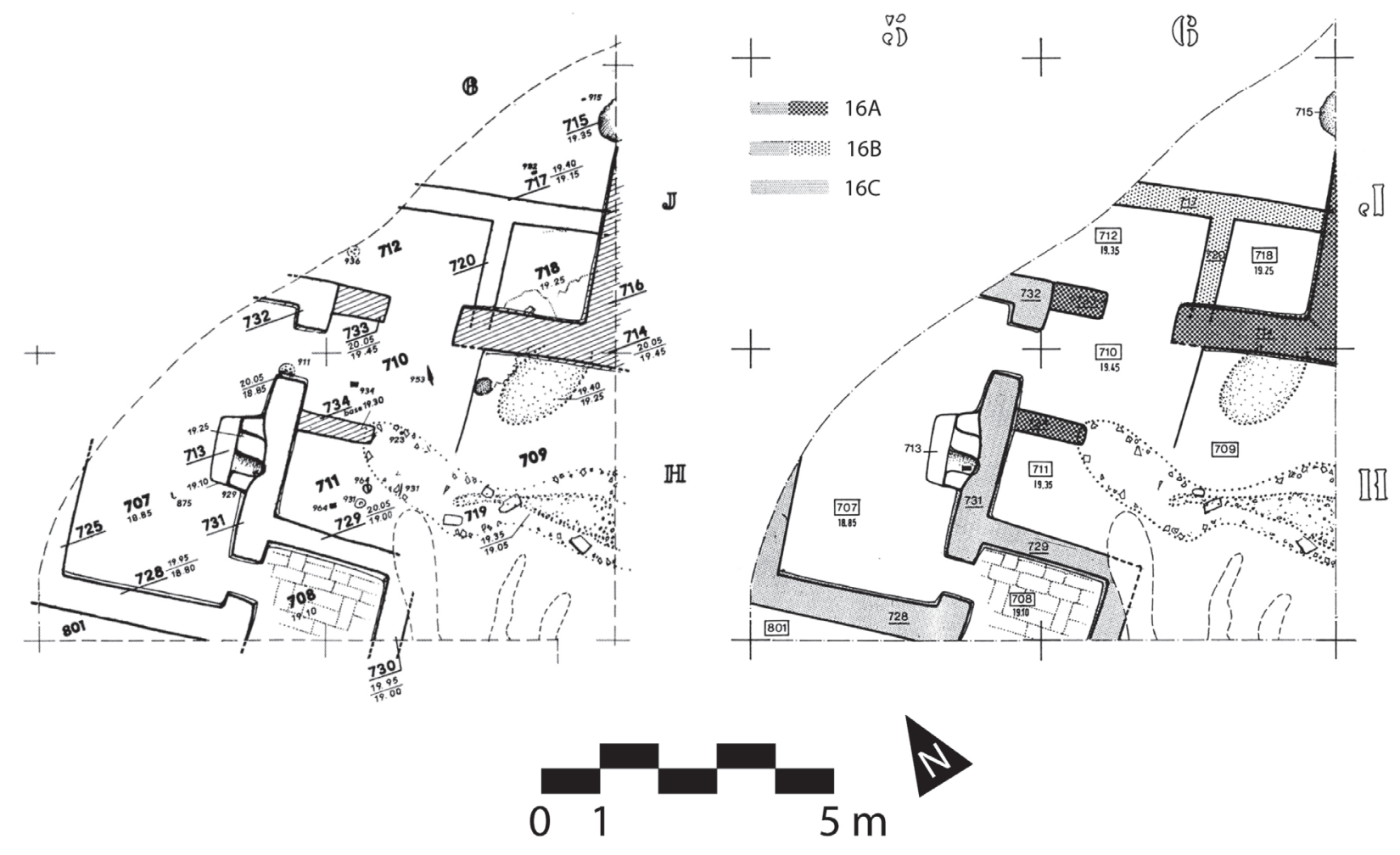

Fig. 3. Susa, Acropolis I layer 16, c. 3000 BC (from Le Brun 1971: fig. 33; 1978: fig. 35).

vessel also appeared in layer 16: "les gobelets à base en moignon/à pied massif" also known as pedestalbased goblet in Tal-i Malyan. ${ }^{24}$ The most specific glyptic styles are the Piemont/glazed steatite style and a more naturalistic one in which animals appear to be acting like humans.

Although the architectural remains discovered by Le Brun are not fully understood due to the limited excavated surface, levels 16 to 14 probably presented a succession of domestic structures. ${ }^{25}$ In layer 16 (Fig. 3 ), the rectangular room 707 (approximate dimensions: L: $5.3 \mathrm{~m}, \mathrm{~W}: 2.7 \mathrm{~m}$; ratio length/width: 1.96 ) exhibited some features linking it directly to rooms 6 and 18 in the Oval enclosure of Godin Tepe, especially a rectangular hearth built in the middle of a long wall with two doors equidistant on either side of the central hearth giving access to two rooms: 708 and $710 / 711 / 712$. As the two different plans published by Le Brun show (see Fig. 3), Le Brun's interpretation of the architectural sequence east of 707, disturbed by

24 Nicholas 1990: pl. 13 u-bb; Sumner 2003: fig. 22 s-ac.

25 Le Brun 1971: 189-205; Stève et al. 2002: col. 416. erosion, slightly varied between 1971 and 1978. Nevertheless, it seems these rooms were notably similar to rooms 15, 16, and 17 north of room 18 in the Oval enclosure of Godin Tepe, since the Susa rooms were also subjected to several modifications.

\section{II.3 Tal-i Malyan}

The ABC and TUV occupations at Tal-i Malyan, in the Iranian province of Fars, date to the late fourth millennium $\mathrm{BC}$ (Middle Banesh period $\approx 3300-3000 \mathrm{BC}^{26}$ ). At that time, Tal-i Malyan was one of the biggest settlements on the Iranian plateau, with an estimated median occupation size of $50 \mathrm{ha},{ }^{27}$ before a $5 \mathrm{~km}$ for-

26 See the numerous and coherent Middle Banesh radiocarbon dates published in Nicholas 1990: table 1; Sumner 2003: 55-56, table 13; Voigt and Dyson 1992, 2: 131, 138; Wright and Rupley 2001: 97; Desset 2012: fig. 2; Dahl et al. 2013: fig. 18.8: Petrie, forthcoming, $b$.

27 Alden 2013: fig. 12.2 and p. 219. Layers with Banesh period 
tification wall was built at the beginning of the third millennium BC (Late Banesh), enclosing an area of 200 ha.

Seven main Banesh architectural layers were excavated in Tal-i Malyan: ABC V, ABC IV, ABC III, ABC II, TUV III, TUV II (all Middle Banesh), and TUV I (Late Banesh). Only the layers ABC IV, ABC III, and TUV II will be considered here (Fig. 4). ${ }^{28}$

In ABC IV and III, the width of the rooms, either square or rectangular, generally did not exceed $3 \mathrm{~m}$, probably due to limitations on the length of the wooden beams used to roof them. Rooms 67 (ABC $\mathrm{IV})$ and 63 (ABC III), however, are larger and may have been covered in a different way. They might also have been unroofed courtyards, although their wellpreserved floors and wall coatings argue against such a hypothesis.

Two building sub-phases were identified in the $220 \mathrm{~m}^{2}$ exposure of ABC IV. The earlier phase (phase IVB) consisted of the south-western corner of a rectangular building (rooms 64, 65, 66, and 67) against which was built (in a later phase-IVA) a double curved wall with stone foundations. The function of the small brick platform in room 64 remains uncertain while area 281, in front of the south-western entrance of the rectangular building, was probably not covered.

The $383 \mathrm{~m}^{2}$ excavated surface in ABC III showed two main north-south walls running the length of the trench (walls 210 and 33). The western wall (wall 210) delimited two different areas: eastwards, a large building with painted walls where circulation was possible between each room (phase IIIC). To the west of wall 210 , the walls defining rooms $269,270,271,228$, 229,230 , and 232 were built in a second stage (phase IIIB), while in the final stage (phase IIIA) three of the IIIB walls (walls 225, 226, and 227) were removed. The only access between these western and eastern parts was through a door between rooms 271 and 267. Room 267 played an important role in circulation in the eastern building since it probably gave access both to a northern wing (rooms 211, 220, 222, 63, and 373) and a southern one (rooms 268 and 34). The walls and floors of the rooms in this level were covered in red,

material were excavated in trenches ABC, TUV, GHI (deep sounding in H5), F26, XX, By8, H1s, TTW1, EE16, and TT-F. Contemporary Susa then only reached 14 ha (without Apadana) or 20 ha (with Apadana).

28 For ABC, see Sumner 1974: 160-64; 1976: 103-6; 1988: 308-9; 2003; for TUV, see Sumner 1976: 106-9; 1988: 309-11; Nicholas 1990. yellow, and white coatings while some decorative panels with red, yellow, grey, and black painted geometric and floral patterns on a white background, unique in the art history of the Iranian plateau in such a remote era, were discovered on top of the fill of level III, which was added to prepare the area for the construction of architectural layer ABC II. ${ }^{29}$

As at Godin Tepe and Susa, the ABC IV and III buildings included a number of rectangular hearths built in the middle of long wall $\mathrm{s}^{30}$ with two doors equidistant on either side (areas 67 and 63). This principle enables some tentative reconstruction of room dimensions when the location of the hearth is known (see Fig. 5 , the interpreted plan of ABC III, with reconstructed rooms 211, 268, and 35).

In TUV II, in an excavated area measuring $455 \mathrm{~m}^{2}$, two buildings were found near an eastern rectangular area (30), possibly a courtyard. The north-eastern building $^{31}$ was probably excavated completely and measured $14 \times 10.5 \mathrm{~m}$. Since it was preserved to a very limited elevation and was also disturbed by an intrusive trench, the thresholds were in general not observed, preventing a clear picture of this building's inner circulation. It seems, however, that this building might have been divided into four equal parts by two perpendicular dividing walls. Rectangular hearths were built in the middle of a long wall in rooms 69 and 363 .

One of the main disadvantages of the building plans revealed in the $\mathrm{ABC}$ trench is that, due to their size, these structures were not excavated in their entirety. The north-eastern building of TUV II may be helpful since it seems to be a smaller complete version of this type of structure (Fig. 5). Levels IV and III of ABC revealed only the south-western corners of large rectangular buildings, characterised by a square corner room used to enable the circulation between the exterior $^{32}$ and two long rectangular rooms, eastwards and northwards (sometimes subsequently divided into smaller square rooms), giving access to probably one of the central areas (either a room or a courtyard) in these buildings, which displayed an significant rectan-

Nickerson 1977.

30 Sumner 2003: 40.

31 Labelled "North Unit" in Nicholas 1990: 30, 34.

32 Sumner (2003: 24), suggested that room 64 in ABC IV might have been a stairwell leading to the building's roof or to a second storey, due to the brickwork structure found in the middle of that room. This structure was probably hampering circulation inside this room. 

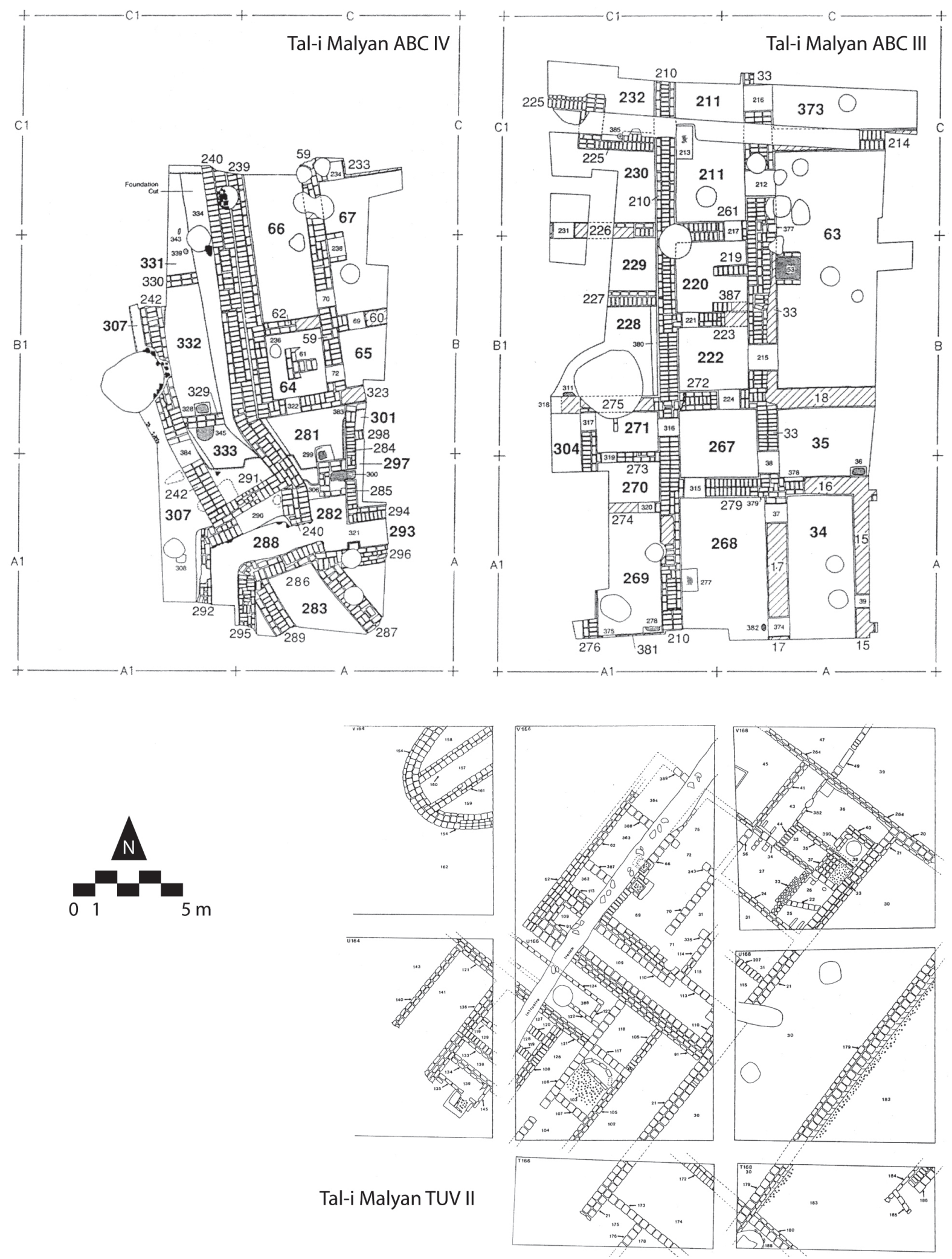

Fig. 4. Tal-i Malyan, Middle Banesh (late fourth millennium BC) architectural layers ABC IV, ABC III, and TUV II (Sumner 2003: figs. 9 and 12; Nicholas 1990: fig. 15). 


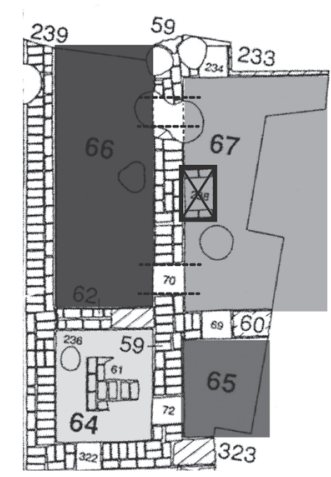

Tal-i Malyan ABC IV
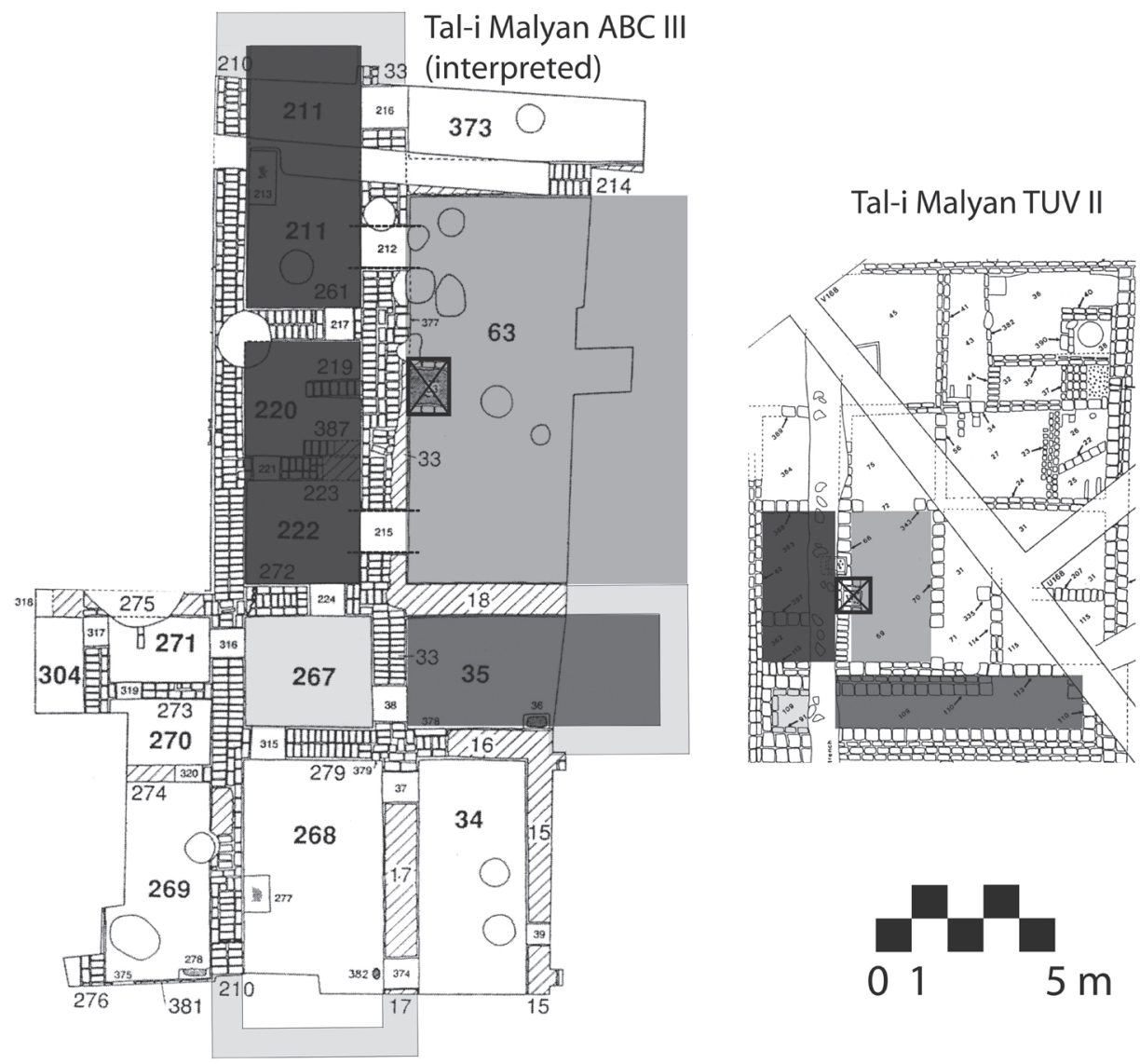

Fig. 5. Interpreted plans of ABC IV, ABC III, and TUV II (restitution of ABC III based on the principle of the location of the hearths in the middle of the walls).

gular hearth built in the middle of a long wall with two doors equidistant on either side. The north-eastern building of TUV II thus probably replicates, in miniature, the general shape of the architectural remains excavated in $\mathrm{ABC}$ IV and III, ${ }^{33}$ while the $\mathrm{ABC}$ plans give indications of the inner circulation in this style of building - an aspect not preserved in TUV II. I propose that the three buildings dug out in ABC IV, ABC III, and TUV II represent a common architectural pattern and testify to a carefully designed building plan.

33 Sumner (2003: 31) proposed to view rooms 63 and 373 in ABC III as similarly sized, since wall 33 is wider than any other wall in this level and doorways through this wall leading into 63 and 373 (doors 212, 215 and 216) display a common width. Due to the quantity of small sherds found in room 211, perhaps caused by heavy foot traffic, Alden (2003: 119) hypothesised that room 211 led to a second (unexcavated) entrance in the ABC III building, to the north of the area exposed in the $\mathrm{ABC}$ excavation.

\section{A COMMON ARCHITECTURAL PATTERN IN LATE FOURTH-MILLENNIUM BC WESTERN IRAN}

\section{III.1 The pattern}

In the late fourth millennium $\mathrm{BC}$, several buildings excavated in Godin Tepe (phase VI.1), Susa (Acr. I.16), and Tal-i Malyan (TUV II, ABC IV, and III, and perhaps also $\mathrm{ABC} \mathrm{V}$ ) displayed a major architectural similarity unnoticed up to now. They all share a fundamental design element (Fig. 6): a rectangular room where a rectangular hearth flanked by two symmetrical doors stood in the middle of a long wall. ${ }^{34}$ For

34 Proportions were not similar. In Godin Tepe, room 18 measured $5.4 \times 3.3 \mathrm{~m}$ (ratio 1.63) and room 6, $4.6 \times 2.8 \mathrm{~m}$ (ratio 1.64); in Tal-i Malyan, area 63 in ABC III measured 10.7 by at least $6.5 \mathrm{~m}$ (ratio 1.64) and room 69 in TUV II, $4.1 \times$ 
convenience, this room will be labelled as a Double Doors Central Hearth (DDCH) room.

At approximately the same period, a rectangular hearth built in the middle of a wall was found in Tepe Yahya IVC2 (the "Proto-Elamite" building) in room $6,{ }^{35}$ while several structures from Arisman (Area C, phase 6) have rectangular hearths built against a wall (but not centred; Fig. 7). ${ }^{36}$ Rectangular hearths built against long walls of rectangular rooms were also found in earlier contexts on the Iranian plateau, dating from the first half of the fourth millennium BC, in level 9 of Tepe Ghabristan (rooms 406 and 407) ${ }^{37}$ and at Tepe Sialk, phase III.4 (room 12). ${ }^{38}$

This pattern reveals an intriguing architectural link between Tal-i Malyan, Susa, and Godin Tepe. The similarity between the Tal-i Malyan ABC III building and the main structure of the Oval enclosure in Godin Tepe (rooms 14, 15, 16, 17, 18, and 19) goes beyond the DDCH room pattern and is evident in the whole building, as compared plans may demonstrate more easily than a verbal description (Fig. 8). ${ }^{39}$ The Susa Acr. I. 16 building, unfortunately, is too fragmentary to allow a similar comparison.

\section{III.2 Hypotheses on the function(s) of the DDCH rooms}

While a room may be used in different ways during its existence, during different seasons, and even on an hour-by-hour basis in a single day, the functions of a room may be approached generally through an examination of its built-in features and its movable furnish-

$2.2 \mathrm{~m}$ (ratio 1.86); in Susa Acr. I.16, room 707 measured 5.3 $\times 2.7 \mathrm{~m}$ (ratio 1.96). In these five cases, their length/width ratios reveal two groups. The first one, with a ratio between 1.60 and 1.65 (Godin Tepe rooms 18 and 6 and Tal-i Malyan ABC III area 63), the second one with a ratio of $c$. 1.9 (Tal-i Malyan TUV II room 69 and Susa Acr.I 16 room 707). The ratio c. 1.63/1.64 in rooms 18 and 6 in Godin Tepe enables us to propose for room 22 a length of $c .6 \mathrm{~m}$ from its width $(3.65 \mathrm{~m})$. [not entirely clear what this means]

35 See notably Potts D.T. 2001: 1-14 and 195-99.

36 Chegini et al. 2011: fig. 9.

37 Madjidzadeh 2008: fig. 72.

38 Ghirshman 1938-39, 1: pl. 60.

39 Considering that the Tal-i Malyan ABC III building was partially excavated, what did its complete plan finally look like? Was it more similar to the Tal-i Malyan TUV II edifice or to the smaller main structure of the Godin Tepe Oval enclosure?

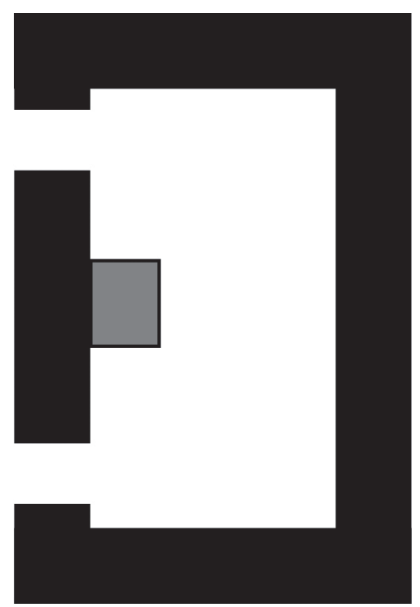

Fig. 6. The late fourth-millennium BC western Iran architectural pattern: the double doors central hearth (DDCH) room.

ings, to the extent that such content is preserved in the archaeological record. ${ }^{40}$

Concerning the first class of remains, the DDCH rooms are above all characterised by a centrally located hearth, ${ }^{41}$ which can be further classified into one of two types (see Fig. 9):

- flat hearths, as evident in Godin Tepe room 18, Tal-i Malyan ABC IV room 67 (a rectangular hearth with a burned plaster surface replastered twice), and ABC III room 63 (several courses of bricks with a plastered surface, probably higher wing walls and perhaps a roof);

— raised-box hearths, ${ }^{42}$ with a raised box over a bed of pebbles or flat sherds on one side and a lower, flat, mud-plastered surface on the other, flanked by bricks, as in Godin Tepe room 6, Susa Acr. I. 16 room 707 (where the lower level was full of ashes and remains from the collapse of the upper part of what was probably a roofed hearth), and Tal-i Malyan TUV II room 69 (a "double hearth" opening also into room 363).

$40 \quad$ Kramer 1982: 96.

41 Hearth 713 in Susa Acr. I.16 room 707 (see Le Brun 1971: 189 and pl. XIX.2); hearth 238 in Malyan ABC IV room 67 (Sumner 2003: 24-25); hearth 53 in Malyan ABC III room 63 (Sumner 2003: 31-32); hearth 68 in TUV II room 69 (Nicholas 1990: 30, 39-41); and the two hearths in rooms 18 and 6 of the Godin Tepe enclosure (Weiss and Young 1975: 3-5, pls. IIa and IIb; cf. Rothman and Badler 2011: fig. 4.20).

42 Well described in Tal-i Malyan TUV by Nicholas (1990: 39-41). 

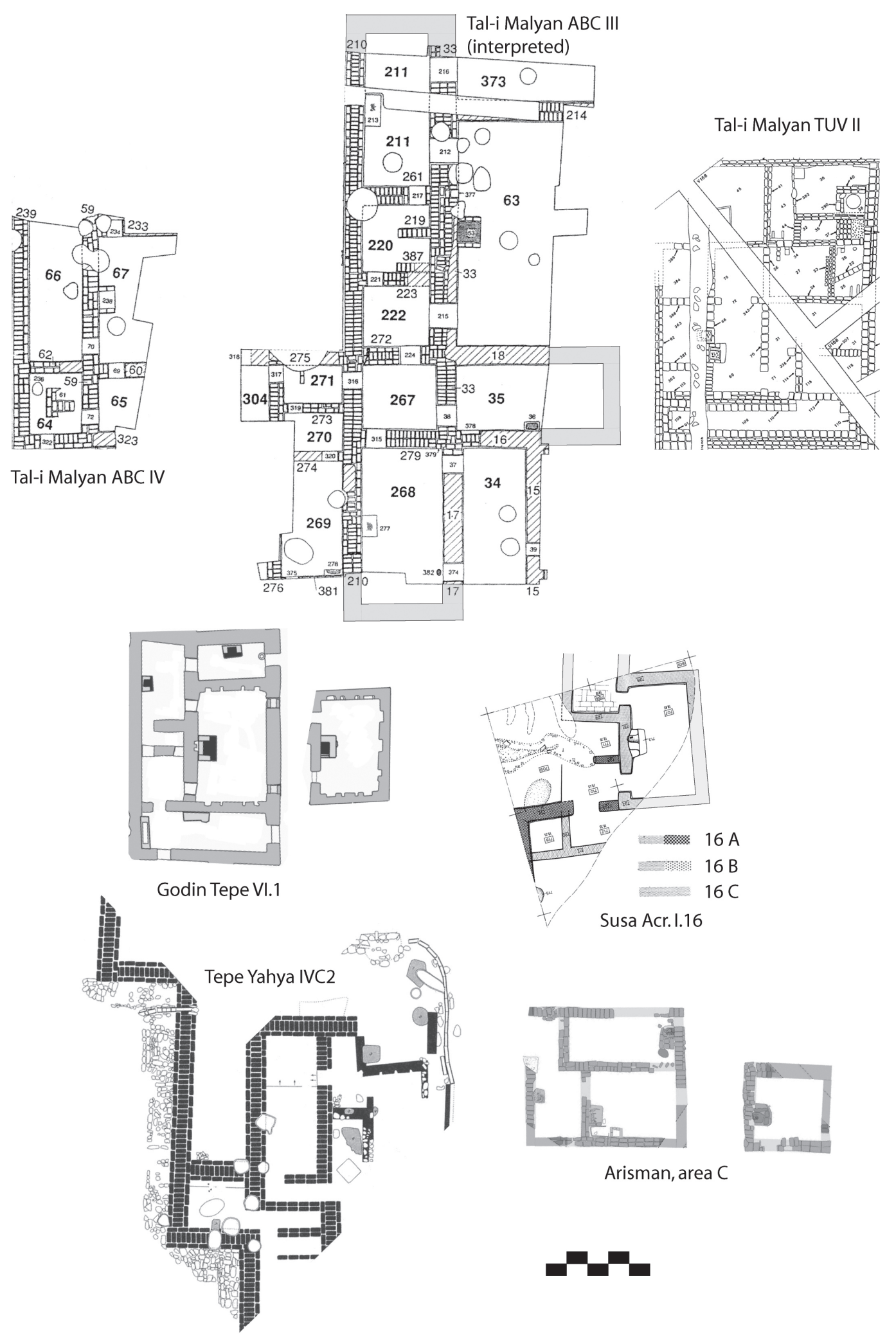

Susa Acr. I.16

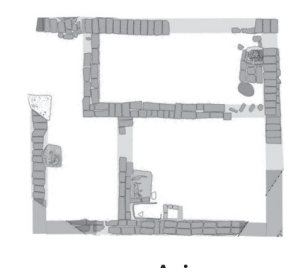

Arisman, area C

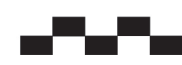

Fig. 7. Compared architecture of Tal-i Malyan, Godin Tepe, Susa, Tepe Yahya, and Arisman in the late fourth millennium BC/c. 3000 BC (common scale). 
Tal-i Malyan ABC III

(interpreted and 'cleaned')

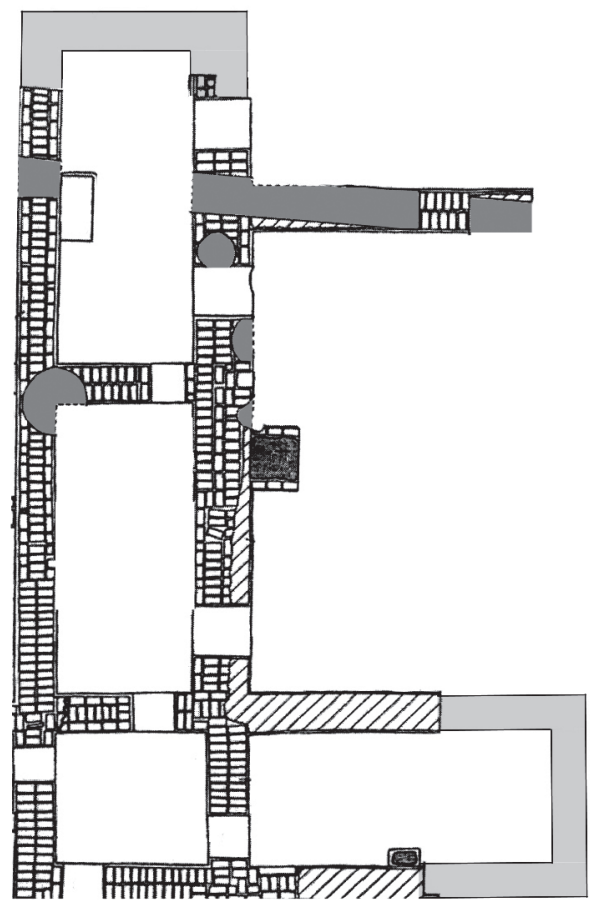

Godin Tepe VI.1

('cleaned')

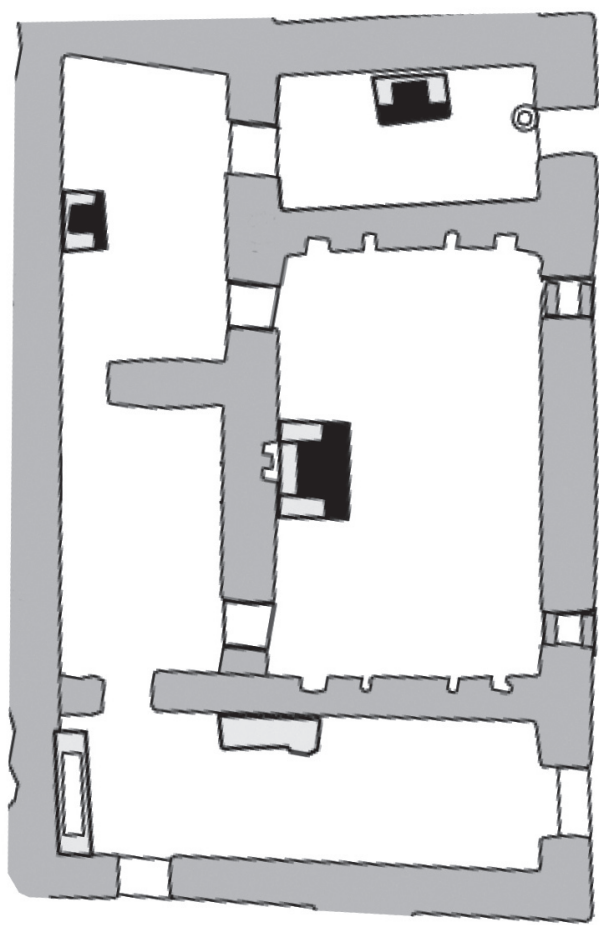

Fig. 8. Compared architecture of the Tal-i Malyan ABC III building (left) and the main structure of the Oval enclosure in Godin Tepe VI.1 (right), late fourth millennium BC (the scales are not respected and the plans were "cleaned" from later additions and modifications).

Weiss and Young, ${ }^{43}$ describing the Godin Tepe hearths, interpreted the first type of hearth as a heating hearth (in rooms 17, 18, 19, and 20) and the second one as a cooking/baking facility (in rooms 5 and 6), ${ }^{44}$ where "the fire was built on top of the raised box and, once the box was thoroughly heated, the ashes then were swept off onto the lower surface and the box top used as a griddle" for baking or cooking. ${ }^{45}$ The distinction between these two types/functions of hearth was not always so sharp, however, as shown by the raised-box hearth 227 in TUV III room 225 (see Fig. 9/5), which was modified to a flat hearth in a second stage, before a new raised box was built. ${ }^{46}$

In practical terms, the functional distinction between these two types of hearth is not so sharp, since

\footnotetext{
$43 \quad 1975: 3$.

44 cf. also Rothman and Badler 2011: 94; Rothman 2013: 82.

45 Nicholas 1990: 39.

46 Nicholas 1990: 40.
}

a hearth used for cooking food will also heat a room and a fire built for heat and light can also be used for cooking. Furthermore, ethno-archaeological studies have shown that sometimes living-room and kitchen functions take place in the same room. ${ }^{47}$ Nevertheless, the flat heating hearth and raised-box cooking/baking hearth dichotomy implies something about the function of the six DDCH rooms identified above. Three of the rooms (Godin Tepe room 18, Tal-i Malyan ABC IV room 67, and Tal-i Malyan ABC III room 63) had flat (heating) hearths while the other three (Godin Tepe room 6, Susa Acr. I.16 room 707, and Tal-i Malyan TUV II, room 69) had raised-box (cooking/baking) hearths. If the primary function of the flat hearths was

47 Horne 1980: 23; Kramer 1982: 105 and 119. On the other hand, Wasilewska (1991) proposed to see in Tal-i Malyan ABC IV and III (as well as in ABC II) the different stages of a temple characterised by "ceremonial altars"-not a very convincing hypothesis. 

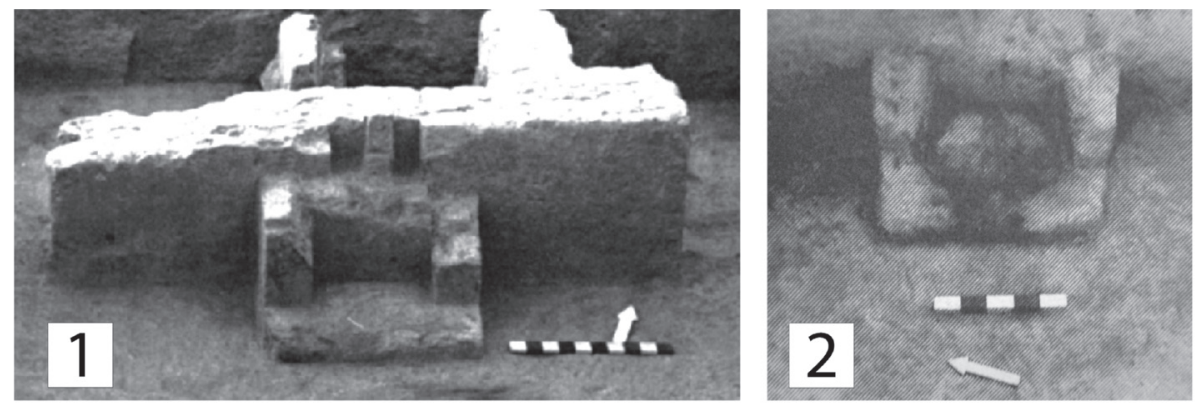

Flat hearths
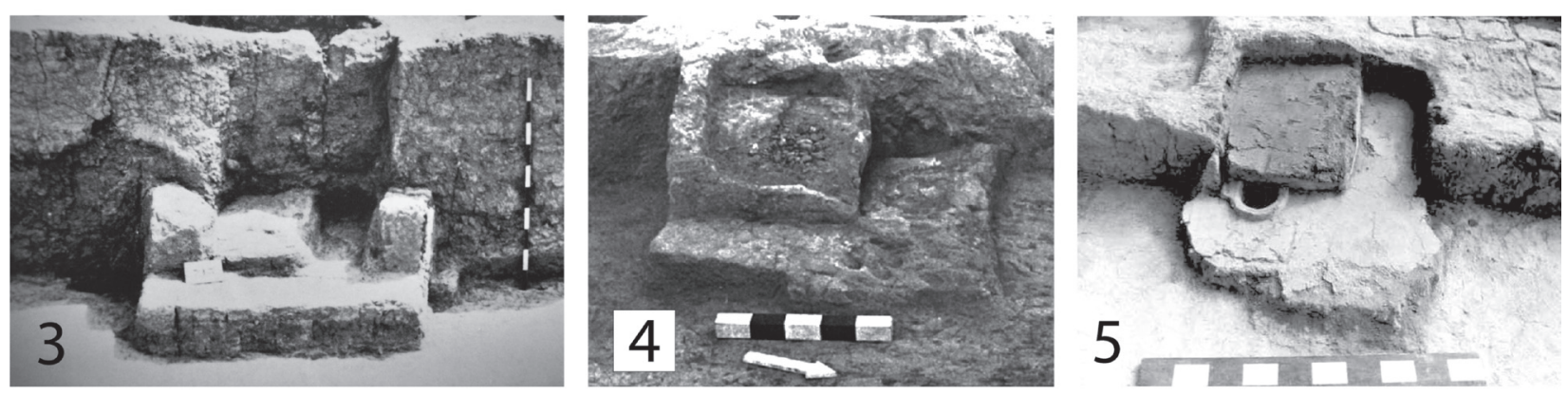

Raised-box hearths

Fig. 9. The two different types of hearths; no. 1: Godin Tepe VI room 18 (Weiss and Young 1975: pl. IIa); no. 2: Godin Tepe VI room 19 (Rothman and Badler 2011: fig. 4. 20); no. 3: Susa, Acr. I.16 room 707 (Le Brun 1971: pl. XIX.2); no. 4: Godin Tepe VI room 6 (Weiss and Young 1975: pl. IIb); no. 5: Tal-i Malyan, TUV III room 225 (Nicholas 1990: pl. 7a).

to provide heat and light, such hearths would presumably be built in living rooms, in places to eat, sleep, receive guests, entertain, store clothes, and carry out domestic handicraft activity such as carving or weaving. Similarly, if the raised-box hearths were designed for cooking they would be found in kitchens, places primarily intended to store and prepare food. More speculatively, this functional distinction may reflect gender-based divisions in the use of space, such as "the kitchen is the domain of women; the living-room, of men" division observed in the ethnographic studies of traditional Iranian architecture. ${ }^{48}$

Besides the built-in features, movable furnishings might help identify the function(s) of a room at the time when it was abandoned. In the rare cases of sudden destruction or hurried abandonment, studies of room contents are obviously relevant; in other situations, such as in Tal-i Malyan ABC (V, IV, and III), where buildings were cleaned and levelled before the

$48 \quad$ Kramer 1982: 102. construction of a new building, remaining artefacts are seldom immediately representative of the ways that rooms and buildings were used.

In Susa Acr. I.16 room 707, a copper hook and some ceramic vessels were found, ${ }^{49}$ although the exact locations of the artefacts and their relationship to occupation surfaces is uncertain since many of them were only documented by the excavation square number where they were found. In Godin Tepe, ${ }^{50}$ room 18 contained 1758 unfired clay balls (which might have been used as weapons, loom weights, and/or blank tablets and sealings); fourteen beads; two bone tools; two stone spindle whorls; a ground stone quern; two lithic cores; some blades and flakes; some storage (notably for grains, wine and beer); cooking, serving, and eat-

$49 \quad$ Le Brun 1971: fig. 67 no. 14; fig. 62 no. 12.

50 Rothman and Badler 2011: 99-106; Rothman 2013: 83-84; see also the artefacts distribution plans in Rothman and Badler 2011: figs. 4.22, 4.23, 4.24; Rothman 2013: figs. 5.4 and 5.5; Matthews 2013: fig. 17.4 . 
ing vessels; and three numeral tablets, including one with a logographic sign. Inside Godin Tepe room 6, archaeologists found some serving ceramic bowls, a spindle whorl, a grinder, a quern, some lithic tools, and a sickle. In the ABC area at Tal-i Malyan, ${ }^{51}$ room 67 (ABC IV) contained a chert flake, some animal bones, and a few ceramic sherds, while room 63 (ABC III) yielded some lithics (blades, flakes), some ceramic sherds, a few shells, a fragment of nacre, a lump of slag; and under hearth 53, sixty bitumen beads, two nacre inlays, and a piece of mineral used to produce beads or cylinder seals. Finally, in the TUV area, room 69 (TUV II) contained a spindle whorl, some remains of chipping stone activity, some faunal remains, some ceramic storage vessels, and a few ceramic sherds.

From these artefacts, we can see these rooms contain a mix of objects relating to food processing (quern and grinder), storage, cooking, serving, and eating (ceramic vessels, faunal remains). There is more limited evidence of handicraft activities (spindle whorls for weaving and chipped stone tools and debitage). At Malyan there was some evidence of shell- and nacreworking. A copper hook was found at Susa, a collection of bitumen beads was found beneath a hearth at Malyan, and numeral tablets and a huge collection of unfired clay balls were discovered in Godin Tepe room 18.

The majority of these finds seem to be related to day-to-day household activity, but in addition, the evidence of food processing and consumption in combination with the distribution of the two types of hearths are a clue, I suggest, that one of the functions, among others, of these DDCH rooms was the reception of guests. The DDCH rooms may have been designed as a kind of formal standardised reception room, a bit like the megaron in second-millennium BC Mycenaean palaces or the parlour of a late nineteenthcentury house. On a day-to-day basis, however, these rooms were used for a variety of practical functions, varying according to the sites and the eras. In any event, it seems certain that the DDCH rooms represent architectural conceptions and perhaps social practices that were widely shared in late fourth-millennium BC western Iran.

51 For ABC IV room 67, see Sumner 2003: 24-25; for ABC III room 63, see Sumner 2003: 32; for TUV II room 69, see Nicholas 1990: 113.

\section{DISCUSSION}

\section{IV.1 Archaeological implications of the DDCH rooms' architectural pattern on the Godin Tepe Oval enclosure}

The existence of this widely shared architectural pattern has many implications, especially on our interpretation of the Godin Tepe Oval enclosure, and also on our conception of the Urukean and Proto-Elamite phenomena in Iran.

At present there is no evidence on the Iranian plateau of any architectural layout comparable to what is observed in Mesopotamia, as would have been expected in the case of a true colonisation of these highland territories by lowland populations..$^{52}$ Indeed, the only Mesopotamian-style tripartite building in all of Iran may be in Chogha Mish in the late fourth millennium BC (Protoliterate phase), although even this building is different from the contemporary Urukean tripartite structures because of its central courtyard..$^{53}$

The buildings inside the Godin Tepe enclosure and at Tal-i Malyan do not share the specific features of contemporary Mesopotamian architecture. Architecture is always a local production. Buildings, after all, cannot be moved, contrary to furniture (in our case, ceramics, glyptic, tablets, and metal and stone artefacts) for which the certainty of local production remains uncommon. To discover, in several widely separated sites, a series of buildings that share a common architectural pattern, seems more meaningful than the shared presence of stylistically similar artefacts, which may have been produced somewhere else. ${ }^{54}$ Similar buildings, separated by hundreds of kilometres (as the crow flies, $645 \mathrm{~km}$ between Godin Tepe and Tal-i Malyan; $259 \mathrm{~km}$ between Susa and Godin Tepe; 464 $\mathrm{km}$ between Susa and Tal-i Malyan), show a pattern of widely shared technical conceptions and indicate that these sites may even have shared social practices perhaps related to a common cultural identity. The hypothesis that the Godin Tepe enclosure represents a Mesopotamian/Urukean/Sumerian outpost established on the Iranian plateau (see above, Introduction) thus

52 Contrary to Habuba Kabira and Djebel Aruda in Syria, where all the material aspects of the southern Mesopotamia way of living (and architecture among others) were fully used; in these contexts, the use of the term "colony" does not seem excessive.

53 Alizadeh 2008: 43-46, fig. 16.

54 Aurenche 1981: 54. 
appears even weaker because of this architectural link with Iranian sites.

\section{IV.2 Independence of the various artefacts categories}

The material aspects of a society's daily life are not necessarily intertwined in a monolithic structure. Many, or perhaps even most, may have been adopted or evolved independently, at various speeds and through different processes, and in contexts whose contemporaneity is beyond our present ability to distinguish archaeologically. ${ }^{55}$

In the case of ceramics, it appears that "Uruk"-related types appeared in various regions of the Iranian plateau around $3500 \mathrm{BC}$, sometimes without a clear break from previous traditions. Examples of such gradual addition of Uruk-related ceramics to a local assemblage occur at Tol-e Spid/Tol-e Nurabad/Tal-e Kureh (where the distinction between the late Lapui and initial Banesh phases is not easy to see), at Tal-i Iblis (in period IV, however poorly defined), and at Tepe Sialk (where "Uruk"-related material is found in late Period III). Nor is it certain if, or how many of, these Uruk types actually have a western origin, that only a chronological anteriority based on absolute dating may prove. ${ }^{56}$ Because of this lack of chrono-

55 Desset et al. 2013: 51.

56 See Wright and Rupley 2001 for the dating of the "Uruk"related assemblages in southern Iraq. The anteriority of these material complexes west of the Iranian plateau is not supported by the data. The oldest radiocarbon dated assemblages of this type in Mesopotamia, and in particular of BRBs (markers of the middle Uruk phase) come from the sites of Abu Salabikh and Tell Qraya. Abu Salabikh dates range between c. 3650-3380 BC and 3950-3660 BC; while at Tell Qraya between $c$. 3900-3370 BC, 3940-3380 BC, and 3950-3380 BC (all calibrated, 95\% probability). The radiocarbon datings of "Uruk"-related layers at Tepe Sharafabad, Tol-e Spid, and Tol-e Nurabad look contemporaneous with those of Abu Salabikh and Tell Qraya (Voigt and Dyson 1992, 2: 129-30; Petrie et al. 2006: 124: Weeks et al. 2006: 68; Petrie 2013b: 391).

To consider that all the so-called "Uruk"-related ceramic types found on the Iranian plateau did not necessarily originate in Mesopotamia may have serious consequences on the historical views expressed so far on this period. This possible paradigm shift was actually initiated by D.T. Potts (2009: 10-12) for the most emblematic "Uruk"-related ceramic type, BRBs: "[...] should we in fact consider the possibility that [the BRBs] originated somewhere to the east of Mesopotamia? [...] It is time to rethink our approach logical clarity, it is not apparent what meaning should be granted to the appearance of these wares across the Iranian plateau.

While the late fourth millennium BC in the Middle East is characterised by an unparalleled but still largely unknown process of inter-regional standardisation that affected the local ceramics assemblages at different moments and on different scales, the evidence assembled in this paper demonstrates that three western Iranian sites show obvious architectural similarities: Susa (Acr. I.16), Godin Tepe (phase VI.1), and Tal-i Malyan (Middle Banesh: ABC IV and III, and TUV II). Nevertheless, as an example of the disconnection between the various material aspects of human societies stated above, PE tablets were used in the buildings of Susa and Tal-i Malyan, while only numeral and numero-logographic tablets were found in the Oval enclosure of Godin Tepe, a pattern illustrating that the DDCH architectural scheme was not linked to a specific writing system.

Because the radiocarbon dates from Godin Tepe and Tal-i Malyan (almost no radiocarbon dates are available for Susa) are not accurate enough to determine the exact chronological relation between the strata containing the DDCH buildings (anteriority/contemporaneity/posteriority $)^{57}$ and to explain this discrepancy between the Godin Tepe and the Susa/Tali Malyan cases, two options seem worth considering:

- either the numeral/numero-logographic tablets (Godin Tepe) were not contemporaneous (even partially) with the Proto-Elamite system (Susa/Tal-i Malyan). This would mean that the architectural pattern revealed in this paper (the DDCH rooms) was in use over an extended period;

- or the numeral/numero-logographic and Proto-

to BRBs and to stop looking at them as non-indigenous, intrusive elements in the many local ceramic traditions in which they appear". For the time being, however, let us just state that the so-called "Urukean" ceramic types found in Iran did not necessarily originate in Mesopotamia and that only new radiocarbon dates could help us investigate the matter further.

57 Due notably to a plateau in the radiocarbon calibration curve between 3350 and 2900 BC (Petrie 2013b: 388; Petrie, forthcoming, b), characterised as "an area of reversal in the incline of the calibration curve where dates that calibrate between 3350-3200 BC end up appearing 'younger' than they should be in comparison to dates that calibrate between 3200-3100 BC, which end up appearing 'older'” (Petrie, forthcoming, a). [I'm assuming 'bc' rather than ' $\mathrm{BC}$ ' is a transcription error?] 
Elamite systems were contemporaneous (at least partially), ${ }^{58}$ the Godin Tepe phase VI.1 (the Oval enclosure) and Tal-i Malyan Middle Banesh phase thus belonging approximately to the same period, ${ }^{59}$ when such an architectural pattern was notably in use. This latter option seems the most likely.

\section{IV.3 The "Proto-Elamite phenomenon"}

The "Proto-Elamite" notion was originally created by Scheil ${ }^{60}$ to qualify a certain type of tablet with regard to its specifically Susian nature (Elam meant Susa in V. Scheil's mind). It is currently used to describe a period, a material horizon $^{61} /$ veneer $^{62}$, and eventually a civilisation, ${ }^{63}$ or more prudently an archaeological "phenomenon", generally conceived as a close consequence of the "Uruk expansion" (concept of "secondary state formation/urbanization/writing development"). It is also believed that, between the end of the fourth and the beginning of the third millennium $\mathrm{BC}$, a powerful political centre might have developed in Fars (or in Susiana), surrounded by a series of peripheral outposts (such as Tepe Sialk or Tepe Yahya) distinguished in terms of culture and language from the hosting communities, and devoted to intercepting and controlling the flows of strategic base materials. ${ }^{64}$ Finally, it is commonly accepted that the material expression of this phenomenon includes a specialised writing system and a distinctive glyptic style, with animals acting or performing like humans, and a peculiar ceramic style..$^{65}$

This last feature is, however, far from being ascertained. The published information on the discovery

58 As stated in Desset 2012: 69-74.

59 Conclusion also reached by Dahl et al. 2013: 363.

60 Scheil 1905.

61 Abdi 2003: 150.

62 Petrie 2013b: 401.

63 For the leapfrogging "semantic inflation" of the "Proto-Elamite" notion, see Abdi 2003.

64 Potts D.T. 1977: 29-30; Alden 1982: 621-24 ("Proto-Elamite polity"); Amiet 1986: 117-19, 210-11 (who mentions a "Proto-Elam"); Lamberg-Karlovsky 1989: xi-xii; Potts T.F 1994: 64-86 ("a powerful and probably centralized politico-economic administration"); Helwing 2004: 45-48; 2005: 50 (the Proto-Elamite phenomenon "may represent a historical or political unit”); Quenet 2008: 113 ("nébuleuse proto-élamite centrée plus ou moins sur Anshan").

65 See for example Carter 1984: 115; 1998; Amiet 1992: 81; Sumner 2003: 1; Helwing 2004: 46, 53; 2013: 97; Quenet 2008: 106. contexts of the PE tablets is only available on five (Susa, Tal-i Malyan, Tepe Yahya, Shahr-i Sokhta, and Tepe Sialk) of the eight sites where these written documents have been found up to now (Susa, Tal-i Ghazir, Tal-i Malyan, Tepe Yahya, Shahr-i Sokhta, Tepe Sialk, Tepe Ozbaki, and Tepe Sofalin; see Fig. 1). Two of these five sites (Tal-i Malyan and Shahr-i Sokhta) were not occupied before the levels containing the tablets. ${ }^{66}$ The three other sites had a gap of variable duration between the layers with the PE tablets and the previous horizons (the interruption was long between phases VA and IVC2 at Tepe Yahya; probably shorter between levels 17 and 16 in Susa, Acropolis I, and between phases III.7 and IV.1 in trench 3 at Tepe Sialk South, separated by a thick layer of $\operatorname{ash}^{67}$ ). To sum up, at present across the second half of the fourth millennium BC Iranian plateau, there is no published archaeological context showing a continuous stratigraphic sequence in a site where PE tablets were found, hence the distorted impression of a ceramic change associated with these tablets. There were potentially only evolutions in "Uruk"-related and local assemblages (ceramics and glyptics), without any connection with the development of a new script. ${ }^{68}$

The so-called "Proto-Elamite phenomenon" only

66 This may not be the case in Tal-i Malyan, however. Sumner (1988: 308) with reasoning based on the surface ceramics samples, stated that Tal-i Malyan was in a way occupied during the Jari, Shamsabad, Bakun, and Lapui periods (sixth to the first half of the fourth millennium BC), while Alden (2013: 219) recently argued that Early Banesh sherds (c. 3400-3300 BC) were found at least in two different areas of the site.

${ }_{67}$ Recent excavations at Tepe Sialk might have uncovered archaeological deposits where the gap described is not present.

68 It is generally assumed that the ceramics and the glyptic of phase IV.1 at Tepe Sialk are related to the Uruk styles. Glassner (1998) and Desset (2012: 16-17), however, showed that part of the tablets from this context are already Proto-Elamite. Does the stratigraphic association of a PE tablet with a BRB modify the nature, considered up to now as "Urukean", of this peculiar ceramic type? In the absence of a tablet, how can we distinguish an "Uruk"-related BRB from a "Proto-Elamite" one (Besenval 1997: 18-19 writes of "proto-élamite" BRBs at Miri Qalat IIIa, probably because of the late dating of the context, c. $3000 \mathrm{BC}$, apparently contemporaneous with the "Proto-Elamite phenomenon" rather than with the "Uruk expansion")? Similar stalemates clearly show the need for a clear distinction between different and independent material aspects of the cultural systems under investigation. 
corresponds to the invention and use of a shared administrative technique (PE writing) in a series of early urban sites on the Iranian plateau between 3300 and $3000 \mathrm{BC}$, approximately in the same period when proto-cuneiform writing appeared in southern Mesopotami $\rightarrow$ ike the latter, the Proto-Elamite system used therrical systems and signs with numeric values of the pre-existing numeral/numerico-logographic tablets. We know that the new writing system was elaborated within communities which, for some still unknown reasons, shared with the west a certain number of so-called "Uruk"-related ceramic types, but we still do not know if the new writing had a definite origin, why and how the writing was adopted and used by other early urban communities, and what intellectual links its inventors had with the administrators who invented the proto-cuneiform system in southern Mesopotamia.

To consider late fourth-millennium BC Iran through two very similar phenomena-Uruk and Proto-Elamite- but distinct because of the writing systems, appears to lead to an impasse. ${ }^{69}$ There might not be a break between these phenomena, but rather only one phenomenon characterised by this still unexplained material (ceramics) standardisation, the common use in Mesopotamia and Iran of the numeral/numero-logographic tablets giving rise in these two areas at the same time to two writing "sisters" (the proto-cuneiform and Proto-Elamite systems) and to which should be added, as this paper has stated, the use of a common architectural pattern in western Iran (at least in Susa, Godin Tepe, and Tal-i Malyan), which is clearly distinct from the Mesopotamian ones.

Apparently running into each other, these various trajectories of standardisation and the differentiation of the material remains found in excavations are not identical. While we can just think through models based on regularities, reality remains hard to conceive, since it seems it did not obey any rules or any general historical movements, various material aspects sometimes contradicting themselves. It may sound quite defeatist, but a reduction of our claims to comprehension is required in the face of the lack of precision of our tools and the non-representativeness of the excavations and surveys. At least new material facts, such as the architectural pattern presented here, may help us to

69 Such as: "il est évident que la nouvelle écriture [Proto-Elamite] exprimait la langue différente d'un peuple différent" (Amiet 1986: 91). catch a glimpse of the seeming complexity of this very fascinating period, leading us towards more restricted, more refined, less systematic, and less brilliant but less inexact statements.

\section{Acknowledgement}

I would like to thank John Alden as well as Maryam Mohammadi, Sepideh Maziar, and Massimo Vidale for their thoughtful comments on an earlier version of this paper. Thank you also to Cameron Petrie for his editing work.

\section{F. Desset \\ University of Tehran/UMR 7041 (ArScAn) \\ Please provide the full address and e-mail}

\section{Bibliography}

Abdi, K. 2003. "From écriture to civilization, Changing Paradigms of Proto-Elamite Archaeology", in N.E. Miller and K. Abdi (eds.), Yeki bud, yeki nabud, essays on the archaeology of Iran in honor of William M. Sumner, The Cotsen Institute of Archaeology, University of California, Los Angeles: 140-51.

Alden, J.R. 1982. "Trade and Politics in Proto-Elamite Iran", Current anthropology 23/6: 613-40.

- 2003. "Sherd size and the Banesh phase occupation in the ABC operation at Malyan, Iran", in N.E. Miller and K. Abdi (eds.), Yeki bud, yeki nabud, essays on the archaeology of Iran in honor of William M. Sumner, The Cotsen Institute of Archaeology, University of California, Los Angeles: 109-20.

- 2013. "The Kur river basin in the Proto-Elamite era, Surface survey, settlement patterns and the appearance of fulltime transhumant pastoral nomadism", in C. Petrie (ed.), Ancient Iran and Its neighbours: local developments and long-range interactions in the 4th millennium $B C$, British Institute of Persian Studies, Archaeological Monographs Series, Oxbow Books, Oxford: 207-32.

Algaze, G. 1989. "The Uruk expansion: cross-cultural exchange in early Mesopotamian civilization", Current Anthropology 43: 199-233.

- 2005. The Uruk world system; the dynamics of expansion of early Mesopotamian civilization, (2nd edition), The University of Chicago Press, Chicago.

Alizadeh, A. 2008. Chogha Mish II, the development of a prehistoric regional center in lowland Susiana, southwestern Iran: final report on the last six seasons of excavations, 1962-1978, Oriental Institute Publications vol. 130, The Oriental Institute of the University of Chicago, Chicago.

Amiet, P. 1986. L'âge des échanges inter-iraniens, 3500-1700 avant $J-C$, Notes et documents des Musées de France 11, 
Éditions de la réunion des musées nationaux, Paris.

— 1992. "Sur l'histoire élamite", IA 27: 75-94.

Aurenche, O. 1981. "L'architecture mésopotamienne du 7ème au 4ème millénaires", Paléorient 7: 43-55.

Badler, V.R. 2002. "A chronology of Uruk artifacts from Godin Tepe in central western Iran and implications for the interrelations between the local and foreign cultures", in J.N. Postgate (ed.), Artefacts of complexity, tracking the Uruk in the Near East, Iraq Archaeological Reports 5, British School of Archaeology in Iraq, Cambridge: 79-109.

Besenval, R. 1997. "Entre le Sud-Est iranien et la plaine de l'Indus: le Kech Makran, Recherches archéologiques sur le peuplement ancien d'une marche des confins indoiraniens", Arts Asiatiques 52: 5-36.

Carter, E. 1984. "Archaeology", in E. Carter and M.W. Stolper, Elam, surveys of political history and archaeology, Near eastern studies vol. 25, University of California Press, Los Angeles: 103-277.

— 1998. "Elam, ii) The archaeology of Elam", EIr 8: 314-25.

Chegini, N.N., Fahimi, H. and Helwing, B. 2011. "Excavations at Arisman, area C", in A. Vatandoust, H. Parzinger and $\mathrm{B}$. Helwing (eds.), Early mining and metallurgy on the western central Iranian plateau, the first five years of work, Archäologie in Iran und Turan vol. 9, Verlag, Philipp von Zabern, Mainz: 40-68.

Dahl, J., Petrie, C.A. and Potts, D.T. 2013. "Chronological parameters of the earliest writing system in Iran", in C. Petrie (ed.), Ancient Iran and Its neighbours: local developments and long-range interactions in the 4th millennium $B C$, British Institute of Persian Studies, Archaeological Monographs Series, Oxbow Books, Oxford: 353-78.

Desset, F. 2012. Premières écritures iraniennes: les systèmes proto-élamite et élamite linéaire, Series Minor no. 76, Dipartimento di Studi Asiatici, Università degli Studi di Napoli “L'Orientale", Naples.

— Vidale, M. and Alidadi Soleimani, N. 2013. "Mahtoutabad III (province of Kerman, Iran), an 'Uruk-related' material assemblage in Eastern Iran", Iran 51: 17-55.

Dittmann, R. 1986. "Susa in the proto-elamite period and annotations on the painted pottery of proto-elamite Khuzestan", in U. Finkbeiner and W. Röllig (eds.), Gamdat Nasr, period or regional style?, Beihefte zum Tübinger Atlas des vorderen Orients, Ludwig Reichert Verlag, Wiesbaden: 171-98.

Forest, J.-D. 1999. 'Les jeux de l'adoption et de l'adaptation: l'emprunt de modèles architecturaux à la Mésopotamie du IVème millénaire", in F. Braemer, S. Cleuziou and A. Coudart (eds.), Habitat et société: XIXème rencontres internationales d'archéologie et d'histoire d'Antibes, Éditions APDCA, Antibes: 167-79.

- 2000. "L'expansion urukéenne: notes d'un voyageur", Paléorient 25/1: 141-49.

Ghirshman, R. 1938-39. Fouilles de Sialk, près de Kashan, 1933, 1934, 1937, 2 vols., Musée du Louvre, Département des antiquités orientales, Série archéologique tome IV, Paul Geuthner, Paris.

Glassner, J.-J. 1998. “Les tablettes dites 'urukéennes' de Sialk IV1", Nouvelles assyriologiques brèves et utilitaires 113: $102-4$.
Helwing, B. 2004. "Tracking the Proto-Elamite on the Central Iranian Plateau", in S.M. Shahmirzadi (ed.), The potters of Sialk, Sialk Reconsideration Project, Report no. 3, Iranian Center for Archaeological Research, Tehran: 45-58.

— 2005. "Early complexity in highland Iran: recent archaeological research into the chalcolithic of Iran", Tüba-ar 8: 39-60.

- 2013. "Some thoughts on the mode of culture change in the fourth millennium BC Iranian highlands", in C. Petrie (ed.), Ancient Iran and Its neighbours: local developments and long-range interactions in the $4^{\text {th }}$ millennium $B C$, British Institute of Persian Studies, Archaeological Monographs Series, Oxbow Books, Oxford: 93-106.

Horne, L. 1980. "Village morphology", Expedition 22/4: 18-23.

Kramer, C. 1982. Village ethnoarchaeology, rural Iran in Archaeological perspective, Academic Press, New York.

Lamberg-Karlovsky, C.C. 1989. "Introduction", The proto-elamite texts from Tepe Yahya, American school of prehistoric research, bulletin no. 39, Harvard University Press, Peabody museum of archaeology and ethnology: v-xiii.

Le Brun, A. 1971. "Recherches stratigraphiques à l'Acropole de Suse, 1969-1971", CDAFI 1: 163-216.

- 1978. "Suse, chantier Acropole 1", Paléorient 4: 177-92.

Madjidzadeh, Y. 2008. Excavations at Tepe Ghabristan, Iran, Reports and memoirs, new series VII, IsIAO, Rome.

Matthews, R. 2013. "The power of writing: an administrative activity at Godin Tepe, Central Zagros, in the late fourth millennium BC", in C. Petrie (ed.), Ancient Iran and Its neighbours: local developments and long-range interactions in the 4th millennium $B C$, British Institute of Persian Studies, Archaeological Monographs Series, Oxbow Books, Oxford: 337-51.

Nicholas, I.M. 1980. "Spatial/functional analysis of the Banesh occupation at Malyan: the TUV operation", Problems of large scale, multi-disciplinary regional archaeological research: the Malyan project, symposium given for the annual meeting of the Society for American Archaeology, Philadelphia, on 01/05/1980.

- 1990. The Proto-Elamite settlement at TUV, Malyan Excavation Report, W.M Sumner, Series editor, vol. 1, University Museum Monograph 69, University of Pennsylvania, Philadelphia.

Nickerson, J.W. 1977. "Malyan wall paintings", Expedition 19/3: 2-6.

Petrie, C.A. 2013a. "Ancient Iran and Its neighbours: the state of play", in C. Petrie (ed.), Ancient Iran and Its neighbours: local developments and long-range interactions in the 4th millennium $B C$, British Institute of Persian Studies, Archaeological Monographs Series, Oxbow Books, Oxford: $1-24$.

- 2013b. "Ancient Iran and its neighbours: emerging paradigms and future directions", in C. Petrie (ed.), Ancient Iran and Its neighbours: local developments and long-range interactions in the 4th millennium $B C$, British Institute of Persian Studies, Archaeological Monographs Series, Oxbow Books, Oxford: 385-411.

— forthcoming, a. "Iran and Uruk Mesopotamia: chronologies and connections in the 4 th millennium BC", in A. Mc- 
Mahon, H. Crawford and J.N Postgate (eds.), Preludes to Urbanism: studies in the Late Chalcolithic of Mesopotamia in honour of Joan Oates, McDonald Institute Monographs, Cambridge.

— forthcoming, b. "Radiocarbon", in B. Helwing (ed.), ARCANE Western Iran.

- Asgari Chaverdi, A. and Seyedin, M. 2006. "Excavations at Tol-e Spid", in D.T. Potts and K. Roustaei (eds.), The Mamasani archaeological project, stage one; a report on the first two seasons of the ICAR-University of Sidney expedition to the Mamasani district, Fars province, Iran, Iranian Center for Archaeological Research, Tehran: 89-134.

Potts, D.T. 1977. "Tepe Yahya and the end of the 4th Millenium on the Iranian Plateau", in J. Deshayes (ed.), Le plateau Iranien et l'Asie centrale des origines à la conquête islamique. Leurs relations à la lumière des documents archéologiques, Colloque no. 567 du C.N.R.S, Paris: 23-32.

- 2001. Excavations at Tepe Yahya, Iran 1967-1975, The Third Millennium, Peabody Museum of Archaeology and Ethnology, Harvard University, Cambridge, MA.

- 2009. "Bevel-rim bowls and bakeries: evidence and explanations from Iran and the Indo-Iranian borderlands", JCS 61: $1-23$.

Potts, T.F. 1994. Mesopotamia and the east, an archaeological and historical study of foreign relations ca. 3400-2000 BC, Oxford university committee for archaeology monograph 37, Oxford.

Quenet, P. 2008. Les échanges du nord de la Mésopotamie avec ses voisins proche-orientaux au IIIème millénaire (ca 3100-2300 av. J.-C.), Subartu 22, Brepols, Turnhout.

Rothman, M.S. 2005. "Transcaucasians: settlement, migration, and trade in the Kura-Araxes periods", AMIT 37: 53-62.

- 2013. "Interpreting the role of Godin Tepe in the "Uruk expansion"”, in C. Petrie (ed.), Ancient Iran and Its neighbours: local developments and long-range interactions in the 4th millennium $B C$, British Institute of Persian Studies, Archaeological Monographs Series, Oxbow Books, Oxford: 75-91.

— and Badler, V.R. 2011. "Contact and development in Godin period VI", in H. Gopnik and M.S. Rothman (eds.), On the High Road, the history of Godin Tepe, Iran, Bibliotheca Iranica: archaeology, art and architecture series 1, Mazda publishers, Royal Ontario Museum: 67-137.

Scheil, V. 1905. "Documents archaïques en écriture proto-élamite", Mémoires de la Délégation en Perse 6: 57-128.

Stève, M.-J., Vallat, F. and Gasche, H. 2002. "Suse", Supplément au dictionnaire de la Bible 73: 359-512.

Sumner, W.M. 1974. "Excavations at Tall-i Malyan, 1971-72", Iran 12: 155-75.
- 1976. "Excavations at Tall-i Malyan (Anshan), 1974", Iran 14: $103-13$.

— 1988. "Maljan, Tall-e (Anshan)", Reallexikon der Assyriologie und vorderasiatischen Archäologie 7/3-4: 306-20.

- 2003. Early urban life in the land of Anshan: Excavations at Tal-e Malyan in the highlands of Iran, Malyan Excavation Reports, William M. Sumner, Series editor, vol. III, University Museum Monograph 117, University of Pennsylvania, Philadelphia.

Voigt, M.M. and Dyson Jr., R.H. 1992. "The Chronology of Iran, ca. 8000-2000 B.C", in R. W. Ehrich (ed.), Chronologies in Old World Archaeology, (3rd edition), 2 vols, The University of Chicago Press, Chicago/London: 122-78 (vol. 1) and 125-53 (vol. 2).

Wasilewska, E. 1991. "To be or not to be a temple? Possible identification of a Banesh period temple at Tall-i Malyan, Iran", Mésopotamie et Elam, actes de la XXXVIème Rencontre Assyriologique Internationale (Gand, 10-14 Juillet 1989), Mesopotamian history and environment, occasional publications 1, Université de Gand: 143-52.

Weeks, L.R., Alizadeh, K.S., Niakan, L., Alamdari, K., Khosrowzadeh, A. and Zeidi, M. 2006. "Excavations at Tol-e Nurabad", in D.T. Potts and K. Roustaei (eds.), The Mamasani archaeological project, stage one; a report on the first two seasons of the ICAR-University of Sidney expedition to the Mamasani district, Fars province, Iran, Iranian Center for Archaeological Research, Tehran: 31-88.

Weiss, H. and Young Jr., T.C. 1975. "The Merchants of Susa. Godin V and Plateau-Lowland Relations in the late Fourth Millennium B.C.”, Iran 13: 1-17.

Wright, H.T. and Rupley, E.S.A. 2001. "Calibrated radiocarbon age determinations of Uruk-related assemblages", in M.S. Rothman (ed.), Uruk Mesopotamia and its neighbors, crosscultural interactions in the era of state formation, School of American Research Press, Santa Fe: 85-122.

Young Jr., T.C. 1986. "Godin Tepe period VI/V and central western Iran at the end of the fourth millennium", in U. Finkbeiner and W. Röllig (eds.), Gamdat Nasr, period or regional style?, Beihefte zum Tübinger Atlas des vorderen Orients, Ludwig Reichert Verlag, Wiesbaden: 212-28.

- 1997. "Godin Tepe", The Oxford Encyclopaedia of Archaeology in the Near East, vol. 2, Oxford University Press, Oxford: 416-17.

— 2004. "The Kangavar survey; periods VI to IV", in A. Sagona (ed.), A view from the highlands, archaeological studies in honour of Charles Burney, Ancient Near Eastern Studies, supplement 12, Peeters, Louvain: 645-60. 